\title{
Chapter 7 \\ Changing Patterns of Industrialization and Emerging States in Twentieth Century China
}

\author{
Toru Kubo
}

\subsection{Introduction}

It might be a problem whether we should study China as an emerging country, because she had her own history as a great empire. But it is obvious that after the middle of the 19th century, China started to struggle for industrial development and eventually achieved it. In particular, industrialization during Mao Zedong's era in the middle of the 20th century left us with such a distinctive impression. So we expect the study on the process of China's industrialization will shed light on the study of the nature of emerging states.

This chapter distinguishes four periods of China's industrialization, and discusses them by referring to the three factors that have shaped the economic development of modern China, the global economy, private enterprises, and the government. Such an understanding will help us to situate Mao's era in the whole process of China's industrialization. We will also make it clear that China had two types of industrialization with particular reference to the significance of the wartime controlled economy under the Nationalist government.

The first factor, the global economy, is mainly reflected on the roles of foreign trade and foreign investment. They include investments in railway construction and the development of domestic river shipping industry and mining and manufacturing industries, which have been beneficial for both the investor countries and China. The second factor, private enterprises, includes large enterprises in cities, smaller enterprises throughout the country, and lots of small-scale industrial activities in the countryside. The third factor is the government, which provided the infrastructure necessary for industrial development, managed state enterprises, and implemented

T. Kubo $(\square)$

Shinshu University, 3-1-1 Asahi, Matsumoto, Japan

e-mail: kubot@shinshu-u.ac.jp

K. Otsuka and K. Sugihara (eds.), Paths to the Emerging State in Asia and Africa, 
various economic policies. In this chapter, I will examine the influences of these three factors in the following four periods of the economic development of modern China.

\subsubsection{Development Led by the Global Economy, 1880s-1900s}

Increasing demand for industrial materials and food stuffs in Europe stimulated Chinese exports of agricultural products. This increase allowed China to import more manufactured goods, including machines for industrialization (Table 7.1). Trade balance was also supported by overseas Chinese remittance and foreign investment (Table 7.2). Foreign investment promoted the development of the Chinese transportation system, especially railway and domestic river steamship lines, which in turn facilitated trade expansion further (Tables 7.3 and 7.4). China's relationship with the global economy stimulated economic development and increased the accumulation of capital, which created conditions fundamental to the development of import substitution industrialization policy. When the First World War began, imports of industrial products from European countries by Asian countries decreased drastically; however, this provided a wonderful opportunity for Asian countries to develop their own industries. China used this opportunity to enlarge several of its industries, such as the cotton and flour industries, and to promote import substitution industrialization.

Table 7.1 General trends of foreign trade, 1871-2013 (100 million US\$)

\begin{tabular}{l|l|l|l|l|l}
\hline \multirow{2}{*}{ Year } & \multicolumn{2}{l|l|l}{ Export } & \multicolumn{2}{l|}{ Import } & \multicolumn{2}{l}{ Balance } & \multicolumn{2}{l}{ Index of quantity } \\
\cline { 2 - 6 } & \multicolumn{2}{|l}{ (Average of three years) } & Export & Import \\
\hline $1871-73$ & 1.11 & 1.07 & 0.04 & 100 & 100 \\
\hline $81-83$ & 0.95 & 1.11 & -0.16 & 123 & 132 \\
\hline $91-93$ & 1.14 & 1.50 & -0.36 & 176 & 230 \\
\hline $1901-03$ & 1.31 & 2.00 & -0.69 & 250 & 391 \\
\hline $11-13$ & 2.77 & 3.59 & -0.82 & 385 & 564 \\
\hline $21-23$ & 5.40 & 7.38 & -1.98 & 508 & 628 \\
\hline $31-33$ & 2.70 & 4.47 & -1.77 & & \\
\hline $51-53$ & 8.67 & 12.20 & -3.53 & & \\
\hline $61-63$ & 15.43 & 13.00 & 2.43 & & \\
\hline $71-73$ & 39.66 & 34.07 & 5.59 & 100 & 100 \\
\hline $91-83$ & 221.94 & 208.99 & 12.95 & 348 & 325 \\
\hline $2001-03$ & 828.71 & 827.75 & 0.95 & & \\
\hline $11-13$ & $3,433.10$ & $3,171.60$ & 261.50 & & \\
\hline
\end{tabular}

Source Kubo et al. (2016: 138) 
Table 7.2 General trends of foreign investment, 1902-2014. Million US\$

\begin{tabular}{l|l|l|l|l|l}
\hline Year & Total & Direct Investment $(\%)$ & \multicolumn{2}{l}{ Loan $(\%)$} \\
\hline 1902 & 788 & 503 & $(63.9)$ & 285 & $(36.1)$ \\
\hline 14 & 1,610 & 1,085 & $(67.3)$ & 526 & $(22.8)$ \\
\hline 31 & 3,243 & 2,532 & $(78.1)$ & 711 & $(21.9)$ \\
\hline 36 & 3,483 & 2,717 & $(78.0)$ & 767 & $(22.0)$ \\
\hline 1985 & 22,947 & 6,060 & $(26.4)$ & 15,547 & $(67.8)$ \\
\hline 90 & 69,602 & 20,691 & $(29.7)$ & 45,673 & $(65.6)$ \\
\hline 95 & 230,665 & 134,868 & $(58.5)$ & 91,255 & $(39.6)$ \\
\hline 2000 & 520,450 & 348,348 & $(66.9)$ & 147,157 & $(28.3)$ \\
\hline 05 & 809,150 & 622,429 & $(76.9)$ & 147,157 & $(18.2)$ \\
\hline 10 & $1,250,443$ & $1,048,381$ & $(83.8)$ & 147,157 & $(11.8)$ \\
\hline 14 & $1,719,861$ & $1,513,256$ & $(88.0)$ & 147,157 & $(8.6)$ \\
\hline
\end{tabular}

Source Kubo et al. (2016: 148)

Table 7.3 Sectoral composition of foreign investment, 1914 and 1931 (\%)

\begin{tabular}{l|c|c}
\hline Year & 1914 & 1931 \\
\hline Industry & 6.9 & 11.6 \\
\hline Mining & 3.7 & 4.0 \\
\hline Transportation & 33.0 & 26.1 \\
\hline Public Utility & 1.7 & 4.0 \\
\hline Trade & 8.8 & 14.9 \\
\hline Finance & 0.4 & 6.6 \\
\hline Estate & 6.5 & 10.5 \\
\hline Military and government & 20.5 & 13.2 \\
\hline
\end{tabular}

Source Kubo et al. (2016: 150)

\subsubsection{Development Led by Private Enterprises Under Protectionist Policy, 1910s-1930s}

Industrialization by private enterprises proceeded under the protectionist policy of the government of the early 20th century. The Industrial Production Index clearly shows marked industrial development from the 1910s to 1930s (Table 7.5, Fig. 7.1). The domestic supply of industrial goods increased during this period (Table 7.6). Many private industrial enterprises were established in China during this period. Such enterprises were successful during the First World War and throughout most of the 1920s. For example, as Chinese cotton mills produced good cotton yarn and low-cost products, they could compete with Japanese cotton mills in the Chinese market. At the same time, China recovered tariff autonomy, which allowed it to pursue a protective policy after 1928. International circumstances during the inter-war 
Table 7.4 Railway construction, 1890-2014 (km)

\begin{tabular}{|c|c|c|c|}
\hline \multirow[t]{2}{*}{ Year } & \multicolumn{3}{|c|}{ Distance in business } \\
\hline & & High speed railway & Foreign management $(\%)$ \\
\hline 1890 & 220 & - & - \\
\hline 1900 & 1,066 & - & - \\
\hline 10 & 8,233 & - & $3,718(45.2)$ \\
\hline 20 & 10,954 & - & $3,755(34.3)$ \\
\hline 30 & 13,807 & - & $4,145(30.0)$ \\
\hline 36 & 20,009 & - & $7,275(36.4)$ \\
\hline 40 & 24,383 & - & $10,229(42.0)$ \\
\hline 46 & 26,857 & - & - \\
\hline 50 & 22,200 & - & - \\
\hline 60 & 33,900 & - & - \\
\hline 70 & 41,000 & - & - \\
\hline 80 & 53,300 & - & - \\
\hline 90 & 57,900 & - & - \\
\hline 2000 & 68,700 & - & - \\
\hline 10 & 91,200 & 5,133 & - \\
\hline 14 & 111,800 & 16,456 & - \\
\hline
\end{tabular}

Source Kubo et al. (2016: 76)

period helped Chinese industrialization. The development of domestic transportation and communication networks and commerce and banking systems were increasing, although the economic relationship with foreign countries did not develop much after the end of the First World War. During this time, Chinese industrialization was mainly limited to the light industry. Although heavy and chemical industries were starting to develop in some areas, they did not have an intimate connection with the domestic light industry. Nevertheless, heavy and chemical industries began to grow in importance as the possibilities of a Japanese invasion and a second world war increased.

\subsubsection{Development Under a Controlled and Planned Economy, 1940s-1970s}

During a period of successive wars (Sino-Japanese War, Second World War, Korean War, Cold War), Chinese economic development became strongly colored by the development of heavy and chemical industries. However, as heavy and chemical industries needed investment and a long lead time to develop, government aid was needed. Almost half of the companies established in Free China during the SinoJapanese War were government-owned companies (Fig. 7.2). This trend became 


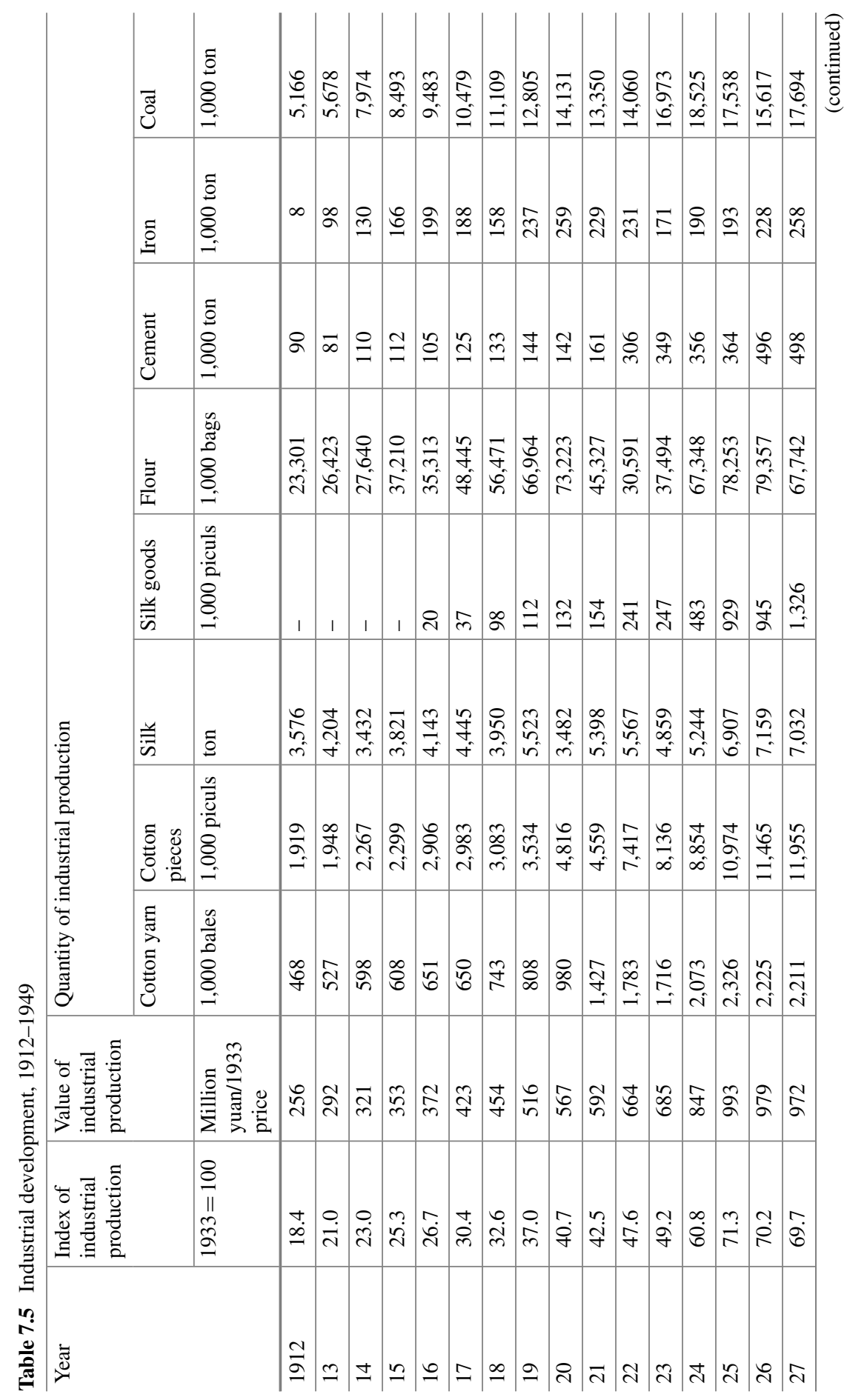




\begin{tabular}{|c|c|c|c|c|c|c|c|c|c|c|c|c|c|c|c|c|c|}
\hline \multirow{8}{*}{ 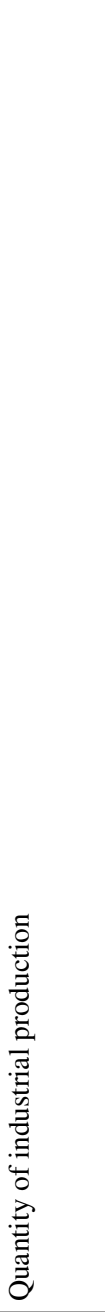 } & $\overline{\tilde{\delta}}$ & $\begin{array}{l}\tilde{0} \\
0 \\
8 \\
0 \\
-1\end{array}$ & $\begin{array}{l}\stackrel{0}{\infty} \\
\text { న్ } \\
\text { I }\end{array}$ & $\begin{array}{l}+ \\
2 \\
\infty \\
\infty \\
\infty\end{array}$ & $\begin{array}{l}\Omega \\
\infty \\
\alpha \\
\Omega\end{array}$ & $\begin{array}{l}\hat{\sigma} \\
\tilde{\sigma}\end{array}$ & 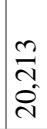 & $\begin{array}{l}n \\
\tilde{o} \\
\tilde{d} \\
\text { in }\end{array}$ & 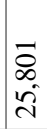 & 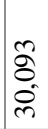 & $\begin{array}{l}\frac{1}{2} \\
m \\
m\end{array}$ & 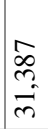 & 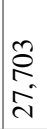 & $\frac{8}{2}$ & 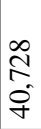 & 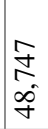 & $\begin{array}{l}\stackrel{\circ}{\alpha} \\
\hat{\sigma}\end{array}$ \\
\hline & ర్ & $\begin{array}{l}0 \\
0 \\
0 \\
0 \\
0 \\
-\end{array}$ & 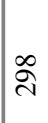 & ర্ల & $\stackrel{\circ}{\infty}$ & $\stackrel{n}{m}$ & $\frac{m}{\gamma}$ & 孚 & $\vec{n}$ & $\stackrel{\infty}{0}^{\infty}$ & $\frac{8}{6}$ & $\bar{\infty}$ & $\frac{0}{a}$ & $\stackrel{\Xi}{\text { I }}$ & 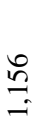 & $\stackrel{n}{2}$ & $\overbrace{0}^{\infty}$ \\
\hline & 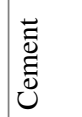 & 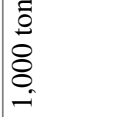 & $\stackrel{\infty}{0}$ & $\stackrel{n}{n}$ & $\overline{8}$ & $\infty$ & $\bar{\sigma}$ & $\widehat{N}$ & $\infty$ & $\widehat{\widehat{\delta}}$ & 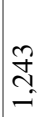 & $\stackrel{2}{0}$ & $\begin{array}{l}0 \\
\text { } \\
-\end{array}$ & $\stackrel{m}{m}$ & 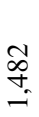 & $\stackrel{+}{n}$ & $\tilde{\Omega}$ \\
\hline & $\frac{\Xi}{\frac{\partial}{I}}$ & $\begin{array}{l}0 \\
0 \\
0 \\
8 \\
8 \\
0 \\
-1\end{array}$ & \begin{tabular}{l}
\multirow{2}{n}{} \\
ñ \\
r.
\end{tabular} & $\frac{0}{=}$ & 年 & $\begin{array}{l}\text { Un } \\
\text { In } \\
=\end{array}$ & $\begin{array}{l}\hat{n} \\
\hat{n} \\
\bar{a}\end{array}$ & $\begin{array}{l}8 \\
0 \\
0 \\
0\end{array}$ & $\begin{array}{l}8 \\
2 \\
2 \\
2\end{array}$ & $\begin{array}{l}2 \\
\varrho \\
\infty \\
\infty \\
0\end{array}$ & $\frac{\hat{\lambda}}{8}$ & బั & $\begin{array}{l}0 \\
\text { ñ } \\
\text { } \\
0\end{array}$ & $\begin{array}{l}\bar{\alpha} \\
\text { ิे } \\
\text { ف. }\end{array}$ & $\begin{array}{l}\hat{\delta} \\
\text { o. } \\
\text { i. }\end{array}$ & $\frac{2}{\sigma}$ & $\frac{8}{8}$ \\
\hline & 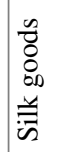 & 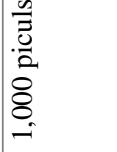 & $\begin{array}{l}+ \\
\stackrel{0}{n}\end{array}$ & ڤે & 車 & $\begin{array}{l}\text { in } \\
\text { rn } \\
\text { in }\end{array}$ & $\begin{array}{l}\mathbb{0} \\
\infty \\
-\end{array}$ & $\begin{array}{l}\infty \\
\infty \\
\infty \\
i\end{array}$ & $\begin{array}{l}8 \\
\text { in } \\
i\end{array}$ & $\frac{\hat{a}}{i}$ & $\begin{array}{l}\infty \\
i \\
i \\
i\end{array}$ & $\hat{n}$ & ठे & $\stackrel{8}{2}$ & $\stackrel{\varrho}{=}$ & $\begin{array}{l}\infty \\
\infty\end{array}$ & $\stackrel{\Re}{\stackrel{\sim}{\sigma}}$ \\
\hline & 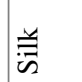 & ฮే & $\begin{array}{l}\vec{n} \\
\text { } \\
\infty\end{array}$ & $\begin{array}{l}2 \\
\hat{\lambda} \\
\infty\end{array}$ & $\begin{array}{l}\bar{n} \\
\hat{\sigma}\end{array}$ & $\begin{array}{l}\infty \\
0 \\
1 \\
0\end{array}$ & 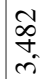 & 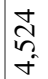 & $\stackrel{m}{m}$ & $\frac{8}{8}$ & $\begin{array}{l}8 \\
\text { के } \\
\text { ले }\end{array}$ & $\frac{\hat{m}}{\stackrel{m}{m}}$ & $\begin{array}{l}\hat{\sigma} \\
i \\
i\end{array}$ & $\begin{array}{l}\stackrel{8}{0} \\
\text { m. } \\
\text { m. }\end{array}$ & $\frac{\infty}{m}$ & $\begin{array}{l}\stackrel{2}{2} \\
\text { in }\end{array}$ & $\widehat{\widehat{\sigma}}$ \\
\hline & 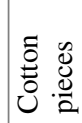 & 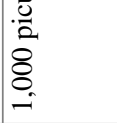 & बे & 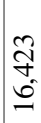 & $\begin{array}{l}n \\
\hat{\sigma} \\
\sigma \\
-\end{array}$ & 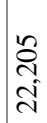 & $\begin{array}{l}\vec{f} \\
\dot{J} \\
\dot{d}\end{array}$ & 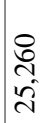 & $\begin{array}{l}n \\
\\
\infty \\
\sim \\
N\end{array}$ & 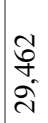 & $\begin{array}{l}\infty \\
\hat{a} \\
\tilde{n} \\
m\end{array}$ & 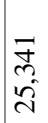 & $\begin{array}{l}\tilde{n} \\
n \\
\infty \\
\infty \\
\text { n. }\end{array}$ & $\begin{array}{l}\infty \\
\infty \\
\infty \\
\tilde{\sigma}\end{array}$ & $\begin{array}{l}8 \\
\text { oे } \\
\text { f }\end{array}$ & $\begin{array}{l}2 \\
\hat{b} \\
8 \\
\text { in }\end{array}$ & $\begin{array}{l}0 \\
n \\
n \\
=\end{array}$ \\
\hline & 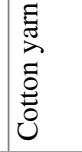 & $\begin{array}{l}0 \\
\frac{0}{\pi} \\
0 \\
8 \\
0 \\
-1\end{array}$ & $\begin{array}{l}\text { w } \\
\text { in } \\
i\end{array}$ & $\begin{array}{l}\infty \\
\sim \\
i\end{array}$ & $\begin{array}{l}\tilde{\Omega} \\
\tilde{n} \\
\tilde{i}\end{array}$ & $\begin{array}{l}0 \\
n \\
n \\
i\end{array}$ & $\begin{array}{l}8 \\
n \\
i\end{array}$ & $\frac{n}{i}$ & $\begin{array}{l}\stackrel{\infty}{2} \\
i\end{array}$ & $\begin{array}{l}\hat{n} \\
\hat{\sigma} \\
i\end{array}$ & તิ & 导 & $\stackrel{\sim}{\stackrel{2}{\sim}}$ & $\stackrel{\hat{\sigma}}{-}$ & $\begin{array}{l}\text { t } \\
=\end{array}$ & $\underset{-}{\stackrel{్}{6}}$ & ס: \\
\hline 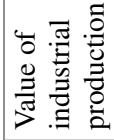 & & 冚冚离 & $\underline{0}$ & $\stackrel{\varrho}{=}$ & $\stackrel{2}{\varrho}$ & 尺) & ֻั & సે & $\stackrel{\widetilde{f}}{\mathscr{f}}$ & กิ & $\begin{array}{l}\infty \\
\infty \\
0 \\
- \\
-1\end{array}$ & $\stackrel{\infty}{\sim} \underset{\sim}{\sim}$ & $\begin{array}{l}\text { aे } \\
\text { î }\end{array}$ & $\mathbb{\delta}_{-}$ & î & $\stackrel{\mathbb{f}}{\stackrel{\sim}{f}}$ & $\stackrel{?}{?}$ \\
\hline 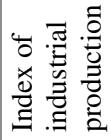 & & $\begin{array}{l}8 \\
11 \\
\infty \\
\sigma \\
\sigma\end{array}$ & $\stackrel{?}{\stackrel{2}{N}}$ & $\stackrel{\infty}{\stackrel{0}{r}}$ & $\stackrel{?}{2}$ & $\stackrel{m}{\alpha}$ & $\stackrel{\circ}{\circ}$ & $\stackrel{0}{8}$ & î̀ & $\stackrel{\stackrel{\Xi}{\ominus}}{ٍ}$ & $\overline{\dot{I}}$ & $\vec{\infty}$ & â & $\begin{array}{l}\circ \\
\stackrel{0}{=}\end{array}$ & $\stackrel{m}{\varrho}$ & $\begin{array}{l}0 \\
\stackrel{0}{0} \\
\qquad\end{array}$ & $\begin{array}{l}m \\
\infty \\
\infty\end{array}$ \\
\hline Ð & & & N & $V$ & m & $\bar{m}$ & กี & $\hat{m}$ & లు & $m$ & లో & $\hat{n}$ & $\stackrel{\infty}{m}$ & ले & q & $F$ & 广 \\
\hline
\end{tabular}


7 Changing Patterns of Industrialization and Emerging ...

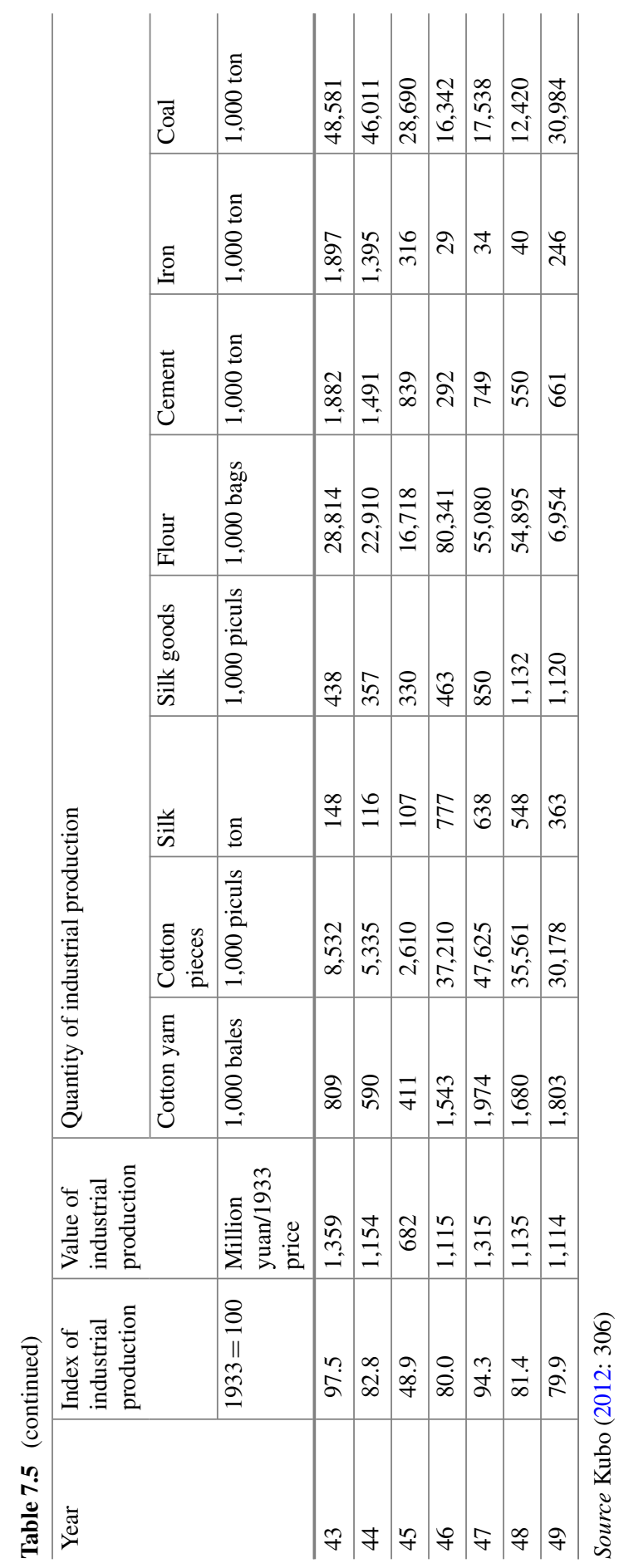




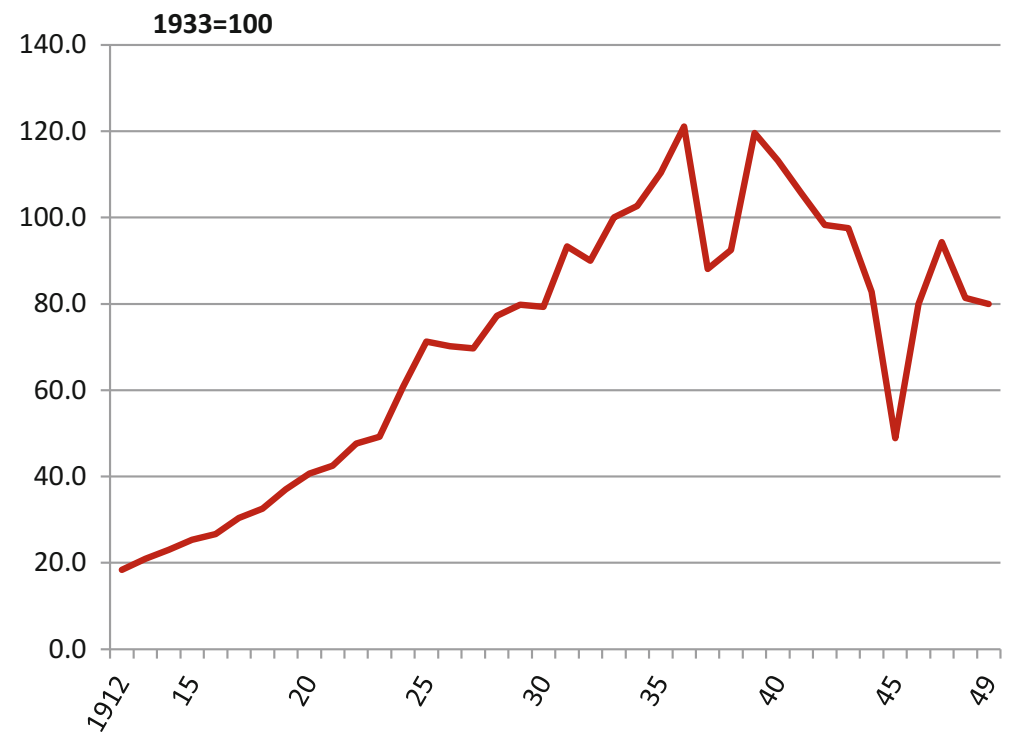

Fig. 7.1 Industrial production index, 1912-1949. Source Table 7.5

Table 7.6 Ratio of domestic supply of Chinese industrial production, 1890-1936 (\%)

\begin{tabular}{l|l|l|l|l}
\hline Year & Cotton yarn & Cotton pieces & Cement & Soda ash \\
\hline 1890 & 5.8 & 1 & $\ldots$ & - \\
\hline 1900 & 40.4 & 7.4 & $\ldots$ & - \\
\hline 10 & 38.4 & 8.2 & $\ldots$ & - \\
\hline 20 & 68.9 & 19.4 & 59.9 & - \\
\hline 30 & 102.3 & 55.3 & 84.6 & 35.6 \\
\hline 36 & 102.3 & 86.5 & 92.0 & 52.7 \\
\hline
\end{tabular}

Source Kubo et al. (2016: 23, 24, 52, 54)

clear when the Communist government emerged in 1949 in response to the Cold War. As heavy and chemical industries rapidly developed from the 1950s to the 1970s, the ratio of heavy and chemical industries of the whole economy markedly increased (Tables 7.7 and 7.8). This was Mao Zedong's era. It can be said that such a path of partial development was possible because light industry had already been sufficiently developed. However, during this period the economic relationship with foreign countries decreased, and the domestic commerce and banking systems declined. In addition, limited investment in the transportation and energy industries damaged them. This resulted in many problems within heavy and chemical industries, but ultimately resulted in marked economic development throughout the 1970s. 


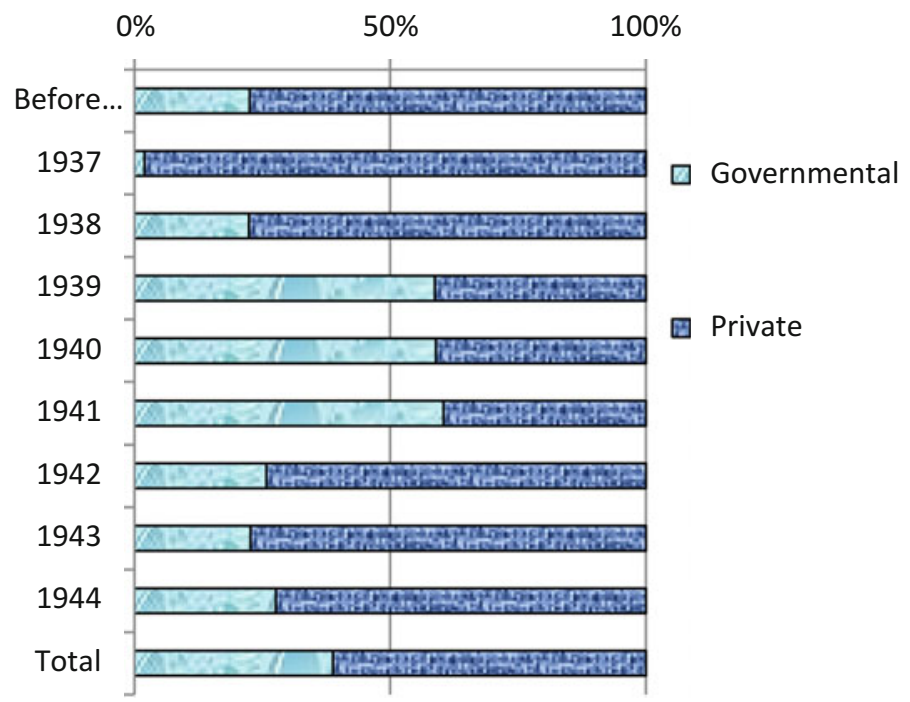

Fig. 7.2 Ratio of paid-in capital of governmental and private companies in free China, 1936-1944 Source Kubo (2004: 183)

Table 7.7 Composition of production, 1933-2014 (value added) (\%)

\begin{tabular}{l|l|l|l|l}
\hline Year & Agriculture & Manufacturing & Service & Total \\
\hline 1933 & 54.1 & 19.6 & 26.2 & 100.0 \\
\hline 36 & 53.4 & 19.8 & 26.8 & 100.0 \\
\hline 40 & 53.2 & 24.7 & 22.2 & 100.0 \\
\hline 52 & 51.0 & 25.2 & 23.9 & 100.0 \\
\hline 60 & 23.6 & 51.6 & 24.8 & 100.0 \\
\hline 70 & 35.4 & 44.8 & 19.8 & 100.0 \\
\hline 80 & 30.2 & 52.9 & 16.9 & 100.0 \\
\hline 90 & 27.1 & 47.6 & 25.3 & 100.0 \\
\hline 10 & 15.1 & 52.1 & 32.8 & 100.0 \\
\hline 14 & 10.1 & 51.4 & 38.5 & 100.0 \\
\hline
\end{tabular}

Source Kubo et al. (2016: 19)

\subsubsection{Further Development with the Global Economy, 1980s-2010s}

The end of 1970s marked the start of the fourth period of economic development in modern China. The agriculture and light industries showed renewed development, and the bias toward development of heavy and chemical industries gradually waned. Improvements in the relationships with Western countries meant that economic rela- 
Table 7.8 Composition of industrial production, 1933-1993 (\%)

\begin{tabular}{l|l|l|l|l|l|l|l|l}
\hline Year & 1933 & 1953 & 1963 & 1970 & 1980 & 1985 & 1990 & 1993 \\
\hline $\begin{array}{l}\text { Fiber } \\
\text { industry }\end{array}$ & 40.0 & 38.1 & 21.8 & 20.9 & 19.5 & 19.1 & 14.5 & 13.1 \\
\hline $\begin{array}{l}\text { Food } \\
\text { industry }\end{array}$ & 34.5 & 35.1 & 26.5 & 16.4 & 14.7 & 13.4 & 14.8 & 12.7 \\
\hline $\begin{array}{l}\text { Metal } \\
\text { industry }\end{array}$ & 4.0 & 6.6 & 15.1 & 14.8 & 11.6 & 9.3 & 12.8 & 17.9 \\
\hline $\begin{array}{l}\text { Machine } \\
\text { industry }\end{array}$ & 4.3 & 7.6 & 17.8 & 24.4 & 26.9 & 31.5 & 30.4 & 27.8 \\
\hline $\begin{array}{l}\text { Chemical } \\
\text { industry }\end{array}$ & 6.4 & 3.7 & 12.5 & 18.8 & 21.4 & 20.5 & 23.4 & 17.4 \\
\hline $\begin{array}{l}\text { Pottery } \\
\text { industry }\end{array}$ & 2.5 & 2.8 & 2.5 & 2.9 & 4.4 & 4.9 & 6.4 & 8.3 \\
\hline $\begin{array}{l}\text { Wood } \\
\text { industry }\end{array}$ & 0.9 & 6.0 & 3.9 & 1.9 & 1.5 & 1.3 & 1.1 & 1.8 \\
\hline $\begin{array}{l}\text { Light } \\
\text { industry }\end{array}$ & 74.5 & 73.2 & 48.2 & 37.3 & 34.1 & 32.5 & 25.3 & 25.8 \\
\hline $\begin{array}{l}\text { Heavy } \\
\text { industry }\end{array}$ & 14.7 & 17.9 & 45.3 & 57.9 & 59.9 & 61.3 & 63.9 & 63.1 \\
\hline
\end{tabular}

Source Kubo et al. (2016: 73)

tionships with foreign countries rapidly increased, eventually reaching the highest level in China's history. The commerce and finance sectors became very active, and the transportation and energy industries also developed. As a result, contemporary China became the second largest economy in the world while maintaining a high rate of economic growth. However, throughout China's economic development, the disparity among provinces and social classes has increased and environmental pollution has become a serious issue, suggesting that economic development will not proceed so smoothly in the future.

\subsection{Industrialization in China}

Scholars generally agree that there are two types of industrialization-capitalintensive industrialization and labor-intensive industrialization. In China, we can find capital-intensive industrialization and labor-intensive industrialization proceeding simultaneously. In this section, as examples of capital-intensive industrialization, I will examine the development of the Chinese cotton and iron industries. Then, as an example of labor-intensive industrialization, I will discuss the development of small cotton mills in Jiangnan, a geographic area covering the lower Yangzi Delta. 


\subsubsection{Development of Machine-Made Cotton Yarn Industry in Big Mills as an Example of Capital-Intensive Industrialization in China}

Increasing imports of foreign machine-spun cotton yarn in the latter half of the 19th century led several western businessmen in China to consider building cotton mills in Chinese open ports. For example, the business plan of British mercantile companies in Shanghai from the 1860 s to 1870 s was to produce machine-spun cotton products that imitated domestic cotton pieces to sell alongside domestic products in the cotton market. However, Chinese cotton merchants protested the plan because it threatened their interests. The Qing government ignored the plan because they were concerned for the livelihoods of the farmers engaged in small-scale weaving and wanted to avoid the promulgation of foreign-managed mills. Thus, ultimately, the plan of the British mercantile companies failed (Suzuki 1992).

The famous comprador and merchant Zheng Guangying (1842-1922) and his colleagues established the first Chinese cotton mill, called the Shanghai Machinemade Cotton Pieces Mill (Shanghai Jiqi Zhibuju), in 1880 with the support of Li Hongzhang (1823-1901), a high-class administrator of the Qing government. The mill began operation in 1890 producing machine-spun cotton yarn and woven products for the domestic market. The plan for the mill did not face any opposition from Chinese merchants dealing in domestic cotton pieces, and received the support of the Qing government (Hatano 1961). It was considered that reducing the imports of cotton products, which accounted for one-third of total imports, would improve the "red ink" in China's trade finances.

After the signing of the Sino-Japanese Peace Treaty in 1895, which granted foreign investors the right to build mills in Chinese open ports, several new cotton mills were established by western mercantile companies in Shanghai (Tanaka 1973). Chinese merchants were able to follow suit and establish their own cotton mills, which cost around C\$200,000 each (approx. US\$150,000 at the 1900 rate), because conditions by then had allowed them to accumulate sufficient capital. From the end of the 19th to the middle of the 20th century, the Chinese cotton industry developed rapidly, arriving at a level of self-supply. They could meet almost all of the domestic needs of machine-spun cotton yarn and about $80 \%$ of the domestic needs of cotton pieces in 1930s (Table 7.9). This kind of development was pursued mainly by Japanese and Chinese cotton mills, rather than by Western cotton mills (Fig. 7.3). In fact, most of the cotton mills established by western mercantile companies failed because of the high costs of management and low profits, and they were ultimately sold to Chinese merchants or Japanese companies (Nakai 1996).

There were several reasons that Japanese cotton mills were able to develop rapidly in China. For example, most Japanese cotton mills built in China had been competitive in the Chinese domestic market, because large Japanese cotton industrial companies had directly invested their capital and technology in China. Also, Japanese cotton companies needed to invest in China because the Japanese domestic market was shrinking. In addition, workers' wages were rising in Japan, a 5\% customs tariff 
Table 7.9 Production and trade of machine-made cotton yarn and cotton pieces, 1880-1990

\begin{tabular}{l|l|l|l|l|l}
\hline Year & $\begin{array}{l}\text { Production of } \\
\text { cotton yarn }\end{array}$ & $\begin{array}{l}\text { Import of } \\
\text { cotton yarn }\end{array}$ & $\begin{array}{l}\text { Production of } \\
\text { cotton pieces }\end{array}$ & $\begin{array}{l}\text { Import of } \\
\text { cotton pieces }\end{array}$ & $\begin{array}{l}\text { Export of } \\
\text { cotton pieces }\end{array}$ \\
\cline { 2 - 6 } & 10,000 tons & 10,000 tons & 1 million $\mathrm{m}^{2}$ & 1 million $\mathrm{m}^{2}$ & 1 million $\mathrm{m}^{2}$ \\
\hline 1880 & - & 0.9 & - & 451.6 & - \\
\hline 90 & 0.4 & 6.5 & 5.2 & 518.2 & - \\
\hline 1900 & 6.1 & 9.0 & 42.3 & 531.6 & - \\
\hline 10 & 8.6 & 13.8 & 50.5 & 566.5 & - \\
\hline 20 & 16.8 & 8.0 & 160.4 & 670.5 & 2.2 \\
\hline 30 & 44.0 & 1.0 & 565.3 & 500.7 & 43.9 \\
\hline 36 & 39.7 & 0.5 & $1,203.1$ & 196.5 & 8.1 \\
\hline 50 & 43.7 & - & $2,520.0$ & - & 27.7 \\
\hline 60 & 109.3 & - & $5,450.0$ & - & 591.7 \\
\hline 70 & 205.2 & - & $7,800.0$ & - & 695.5 \\
\hline 80 & 292.6 & - & $8,710.0$ & - & $1,086.3$ \\
\hline 90 & 462.6 & - & $10,825.0$ & - & $2,221.6$ \\
\hline
\end{tabular}

Source Kubo et al. (2016: 24-25)

Fig. 7.3 a Proportion of spindles in Chinese and foreign cotton mills, 1894-1936, b proportion of weaving machines in Chinese and foreign cotton mills, 1894-1936 Source Kubo et al. (2016:25)
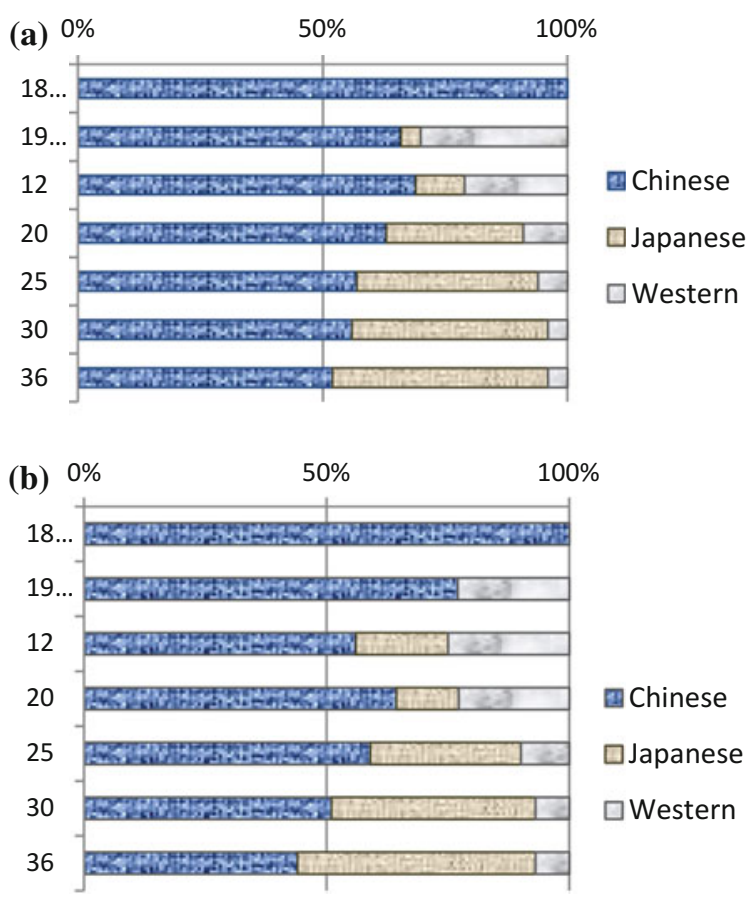
Table 7.10 Geographical distribution of spindles of Chinese and Japanese cotton mills in China, 1922-36. Unit: 1,000 spindles; () index $(1930=100)$

\begin{tabular}{|c|c|c|c|c|c|c|}
\hline \multirow[t]{2}{*}{ Year } & \multicolumn{2}{|l|}{ Shanghai } & \multirow{2}{*}{$\begin{array}{l}\text { Yangzi } \\
\text { Delta } \\
\text { Chinese }\end{array}$} & \multicolumn{2}{|c|}{$\begin{array}{l}\text { North China, Costal } \\
\text { Cities }\end{array}$} & \multirow{2}{*}{$\begin{array}{l}\text { North China, } \\
\text { Inland } \\
\text { Chinese }\end{array}$} \\
\hline & Chinese & Japanese & & Chinese & Japanese & \\
\hline \multirow[t]{2}{*}{1922} & 624 & 587 & 420 & 230 & 85 & 165 \\
\hline & (65) & (51) & (81) & (104) & (22) & (65) \\
\hline \multirow[t]{2}{*}{1930} & 953 & 1,148 & 518 & 221 & 379 & 255 \\
\hline & (100) & (100) & (100) & (100) & (100) & (100) \\
\hline \multirow[t]{2}{*}{1936} & 1,117 & 1,331 & 672 & 112 & 689 & 330 \\
\hline & (117) & (116) & (130) & (51) & (182) & (130) \\
\hline
\end{tabular}

Source Kubo et al. (2016: 27)

Notes Yangzi Delta includes Jiangsu and Zhejiang provinces. North China, Costal Cities includes Qingdao and Tianjin

was imposed in China, and the technical disparity between Japanese and Chinese cotton mills was closing, resulting in a loss of competitiveness of exports of Japanese cotton products made in Japan; thus, the Japanese cotton industry needed to invest in building mills in China (Takamura 1982).

Chinese cotton mills were in direct competition with Japanese mills in China. By classifying the number of spindles by location and mill-owner nationality, we can see that Japanese cotton mills were dominant only in the coastal cities in North China, which are areas where Japan was applying strong political and military pressure (Table 7.10). In Shanghai and other districts, Chinese cotton mills were dominant. Regarding profit rates, Chinese cotton mills (such as Yong-an or Shenxin in Shanghai, Huaxin in Xi County, and Jinhua in Yuci City), had profit rates comparable to those of Japanese mills (Fig. 7.4). Yong-an or Shenxin in Shanghai had stable management fundamentals and relatively advanced technology. In addition, they could use cheap raw cotton imported from foreign countries. In contrast, Huaxin in Xi County in Henan Province, Jinhua in Yuci City in Shanxi Province, and other such mills built in inner districts had a superior location to buy raw cotton directly from farmers and also to sell cotton yarn directly to weavers. Other factors important for the development of the Chinese cotton industry included (1) decreased imports due to the First World War, (2) implementation of a protective tariff policy implement by the Nationalist government from the end of the 1920s to the 1930s, (3) improved movement of raw cotton as a result of the cooperation between the government and private companies, and (4) increased domestic supply of spinning and weaving machines (Kiyokawa 1983).

In particular, the domestic supply of spinning and weaving machines had a very important affect on promoting the transfer of technical knowledge from developed countries to developing countries. The first generation of cotton mills established at the end of the 19th century imported all of their spinning and weaving machinery from the West and invited Western engineers to oversee operation of this machinery. How- 


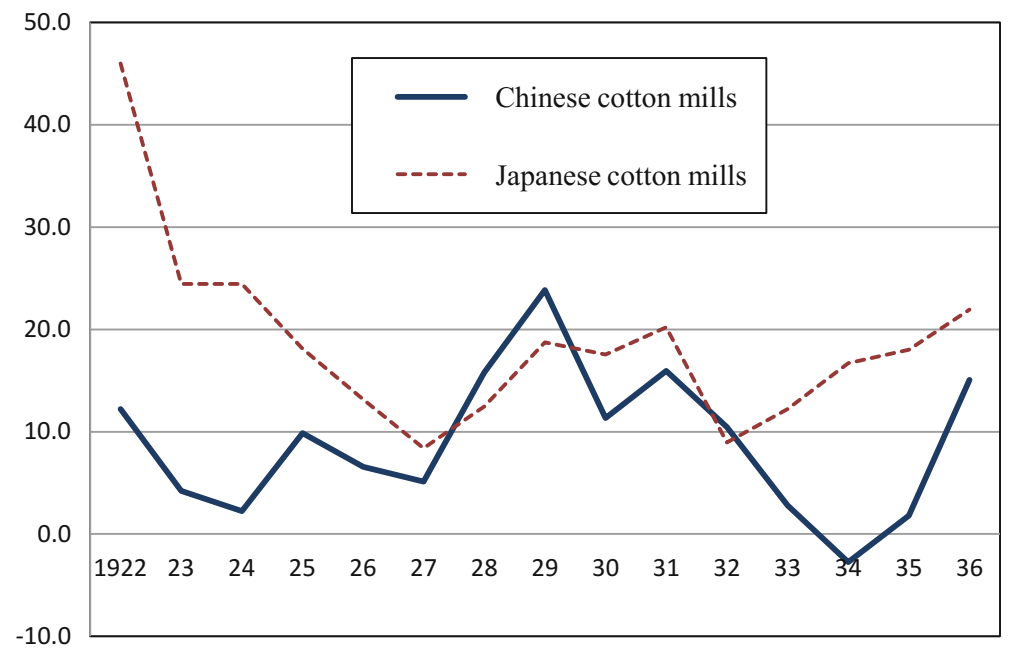

Fig. 7.4 Profit rates of Chinese cotton mills and Japanese cotton mills in China, 1922-36. Source Kubo et al. (2016: 28)

ever, this technological transfer had various knock-on effects from the 1920s to the 1930s. For example, Dalong Machinery Manufacturing in Shanghai began to make cotton-spinning machines from 1936, although the quality of these machines was somewhat low. However, technological developments by factories such as Zhongguo Fangzhi Jianshe Gongsi (Chinese Cotton Industry Constructing, CCIC) Shanghai No. 1 Machinery Manufacturing (formerly Toyoda Boshoku Sho Tekkobu, established in 1935), CCIC Shanghai No. 2 Machinery Manufacturing (formerly Naigaiwata Tekkosho, established in 1941), and CCIC Qingdao No. 1 Machinery Manufacturing (formerly Toyoda Tekkosho, established in 1938 with two others) continued the development of Japanese cotton mills in China.

The system for educating engineers was also developed with Dasheng Cotton Mill in Nantong and Shenxin Cotton Mill in Wuxi in the 1910s. The School of Spinning and Weaving (Fangzhi Chuanxisuo), a famous educational organization in modern China, was attached to Dasheng Cotton Mill in Nantong in Jiangsu Province in 1912, changed its name to Nantong College (Nantong Xueyuan) in 1930, and had educated 1,750 engineers by 1952. Beijing Business High School (Jingshi Gaodeng Xuetang), Beiyang University (Beiyang Daxue), and Tianjin Industrial High School (Tianjin Gaodeng Gongye Xuetang) were founded in northern China between the end of the Qing and the early Republican period, all of which had a major in spinning or weaving. At the same time, in Yangzi Delta, Suzhou Industrial High School (Suzhou Gongye Zhuanmen Xuexiao) and Hangzhou Industrial Business High School (Hangzhou Gaoji Gongye Zhiye Xuexiao) also started to educate spinning and weaving engineers (Zhongguo Jindai Fangzhishi Bianweihui 1996-1997). The spinning and weaving educational system developed in Shanghai when the cotton industry was expanding under the conditions created by the Sino-Japanese War. 
These developments in the educational system provided valuable manpower for the Chinese cotton industry when the Japanese abandoned their cotton mills in China at the end of the Second World War.

The Sino-Japanese War also had a huge influence on the development of the Chinese cotton industry. Overall, the level of production decreased during the war not only because of direct war damage but also because of the removal of equipment by the Japanese Army. However, Japanese cotton mills in China were still able to make a profit during the war because of the rise in the price of cotton products. In addition, the Japanese Army assumed management of captured Chinese cotton mills (Takamura 1982). Despite the circumstances, Chinese cotton mills operating in the Shanghai settlement were still able to make a profit (Wang 1990). Moreover, many small cotton mills were able to escape being taken over by the Japanese Army. Newly established Chinese cotton mills in Free China, especially in Sichuan or Shanxi, also developed and were successful.

After the end of the Sino-Japanese War, the Nationalist Government took over the Japanese cotton mills as part of the reparation agreement and one state company, China Spinning and Weaving Construction Company (CSWCC; Zhongguo Fangzhi Jianshe Gongsi), began to manage all of the mills. Originally, the intention was to sell the mills to private companies after three years (Kawai 1987). However, before the three years had passed, the Nationalist Government fell and the People's Republic of China emerged. The central government of the People's Republic of China took over not only CSWCC but it also nationalized other private cotton mills until eventually all of the cotton mills in China were under government control. This was because the central government prioritized financing the national budget and supplying the population with clothes. According to trial accounts, the profit rate for cotton yarn reached $26 \%$, which provided the central government with $\mathrm{C} \$ 10$ billion within five years (Onoe 1971). This prompted the central government to invest intensively in improving the equipment of the cotton industry, using from 80 to $90 \%$ of the total investment for the fabric industry. Particular attention was paid to develop the cotton industry in districts such as Xian or Shijiazhuang as part of the central government's economic strategy to develop inner China. Many engineers in the cotton industry were educated from the 1930s to the 1940s, and technology transfer progressed via Japanese cotton mills during the same period. Such achievements in the Republican period undoubtedly helped the government of the People's Republic of China pursue their policies.

\subsubsection{Development of the Iron and Steel Industries Before 1949 as a Second Example of Capital-Intensive Industrialization in China}

The starting point of China's development of iron and steel industries was the establishment of Hanyang Iron Foundry (Hanyang Tiechang) in 1894. The founder, Zhang 
Zhitong, a high-class administrator of the Qing government, wished to develop an industrial base in Wuhan district, which was where he was posted at the time, and to supply steel for the construction of a railway between Wuhan and Beijing (Hatano 1961). However, because the Hanyang Foundry used the Bessemer process, which was not suitable for their phosphorus-rich iron ore, and they needed to import coke from Britain, and because Wuhan was far from the iron ore and coal mines, the iron produced by the Hanyang Foundry was very expensive and was not suitable for railway construction (Chuan 1972).

After the Hanyang Foundry introduced a Martin-Siemens open-hearth furnace, which was suitable for their Daye iron ore, and built a new railway to bring coal from Pingxiang coal mine, they finally succeeded in producing high-quality iron. At that time, Hanyang Foundry became part of a large united company called the HanYe-Ping Company (Han-Ye-Ping Gongsi) in 1908. However, such improvements needed additional investment, but since this was too much of a financial burden for the Qing government to accept, Han-Ye-Ping Company introduced private capital and Japanese debt.

However, the management of Han-Ye-Ping Company itself were experiencing problems. Private investors demanded high dividends, and the company did not have enough assets to strengthen its competitiveness. As soon as the post-war depression began after the end of the First World War, it faltered until finally it stopped production in 1925.

While the Han-Ye-Ping Company was in decline, the Japanese iron industry in Manchuria, including the Anshan Foundry and the Benxihu Foundry, was rapidly developing (Table 7.11). In Anshan, the Japanese attempted to get mining rights of iron ore under a joint Sino-Japanese company. China, which had enacted the law to protect domestic mining rights, saw that this joint venture was to be effectively under Japanese control, and resisted to grant the rights in April 1916. Aggressive negotiations by Japan continued, however, and eventually forced the compromise. A large Japanese state-owned company, South Manchuria Railway Company thus began to build the Anshan Foundry in October 1916, which started operation in April 1919 (Nakura 1984). In Benxihu, after Japan secured the rights to engage in mining there under the Sino-Japanese Agreement on Five Problems in Manchuria in September 1909, Benxihu Coal Mining Company, led by Okura Financial Group, was established in May 1910. The company changed its name to Benxihu Coal and Iron Company in October 1911 and started operation in January 1915 (Murakami 1982). This process shows that the Japanese iron industry in Manchuria was realized due to Japanese imperialistic policy pursued before and after the First World War.

The development of both foundries cannot be separated from the development of Japanese imperialism. Anshan Foundry had to invest heavily to deal with the low iron content of the ore it used. Nevertheless, South Manchuria Railway Company supported the foundry by supplying cheap coal, discounting railway fares, and providing a special low assessment of depreciation. In addition, South Manchuria Railway Company itself invested heavily in developing new methods to deal with the low iron content of the ore until high-output low-cost production could be achieved. In the case of Benxihu Foundry, because they were already producing high-quality 
Table 7.11 Production of iron foundries, 1919-37 (1,000 tons)

\begin{tabular}{l|l|l|l|l|l}
\hline \multirow{2}{*}{ Year } & \multicolumn{3}{|l|}{ Mainland } & \multicolumn{2}{l}{ Manchuria } \\
\cline { 2 - 6 } & Hanyang & Baojin & Yangzi & Anshan & Benxihu \\
\hline 1918 & 139 & - & - & - & 45 \\
\hline 19 & 166 & - & - & 32 & 79 \\
\hline 20 & 126 & - & 8 & 76 & 49 \\
\hline 21 & 124 & - & 15 & 58 & 31 \\
\hline 22 & 148 & $\ldots$ & 15 & 67 & - \\
\hline 23 & 73 & $\ldots$ & - & 73 & 24 \\
\hline 24 & 27 & $\ldots$ & 15 & 96 & 52 \\
\hline 25 & 53 & $\ldots$ & - & 90 & 50 \\
\hline 26 & - & 5 & - & 165 & 51 \\
\hline 27 & - & $\ldots$ & - & 203 & 51 \\
\hline 28 & - & 5 & 6 & 224 & 63 \\
\hline 29 & - & 3 & 11 & 210 & 76 \\
\hline 30 & - & 3 & - & 288 & 85 \\
\hline 32 & - & 6 & 4 & 269 & 66 \\
\hline 33 & - & - & 19 & 300 & 81 \\
\hline 34 & - & 4 & 17 & 347 & 153 \\
\hline 35 & - & 3 & $\ldots$ & 472 & 151 \\
\hline 36 & - & $\ldots$ & $\ldots$ & 492 & 160 \\
\hline 37 & - & $\ldots$ & $\ldots$ & 677 & 136 \\
\hline & & & & &
\end{tabular}

Source Kubo et al. (2016: 66)

steel for ship building and arms manufacture for the Japanese Navy due to their supplies of high-quality coal and iron ore, the foundry was able to secure a low-rate loan from the Japanese government to develop their management. Both of the Japanese foundries established in Manchuria developed under Japanese state organization and policy, exporting most of their products to Japan (Table 7.12). Thus, these products were not a part of China's national economy until Japan's defeat in 1945.

In mainland China, the Nationalist Government planned to establish new stateowned foundries after the decline of Han-Ye-Ping Company in the 1930s and 1940s. The plan to build a new foundry in Ma'anshan near Nanjing proceeded with German support before 1937; however, the location was changed to Zhuzhou in Hunan Province because of the threat of a Japanese invasion. But even this new plan could not be realized because of the outbreak of the Sino-Japanese War in 1937 (Hagiwara 2000). However, the Nationalist Government established several small foundries in Free China during the Sino-Japanese War and these foundries played a very important role in supporting China's resistance against Japan, even though their production was only 77,000 tons per year at its peak.

Japan's defeat fundamentally changed the situation of the Chinese iron industry. Former Japanese foundries in Manchuria were taken over by the army of the 
Table 7.12 Sales of Anshan and Benxihu foundries (1,000 tons (\%))

\begin{tabular}{l|l|l|l|l|l|l}
\hline \multirow{2}{*}{ Year } & \multicolumn{4}{|l|}{ Anshan Foundry } & \multicolumn{3}{l}{ Benxihu Foundry } \\
\cline { 2 - 7 } & Total(A) & $\begin{array}{l}\text { For Japan } \\
\text { (B) }\end{array}$ & $\%(\mathrm{~B} / \mathrm{A})$ & Total(A) & $\begin{array}{l}\text { For Japan } \\
(\mathrm{B})\end{array}$ & $\%$ (B/A) \\
\hline 1923 & 77 & 57 & $(74)$ & 24 & 15 & $(63)$ \\
\hline 24 & 81 & 62 & $(76)$ & 53 & 37 & $(71)$ \\
\hline 25 & 113 & 87 & $(77)$ & 51 & 39 & $(76)$ \\
\hline 26 & 147 & 121 & $(83)$ & 49 & 37 & $(76)$ \\
\hline 27 & 208 & 175 & $(84)$ & 53 & 37 & $(69)$ \\
\hline 28 & 212 & 172 & $(81)$ & 62 & 38 & $(62)$ \\
\hline 29 & 200 & 160 & $(80)$ & 76 & 52 & $(69)$ \\
\hline 30 & 163 & 120 & $(74)$ & 74 & 48 & $(66)$ \\
\hline 31 & 277 & 227 & $(82)$ & 65 & 51 & $(78)$ \\
\hline 32 & 350 & 309 & $(88)$ & 88 & 74 & $(84)$ \\
\hline
\end{tabular}

Source Kubo et al. (2016: 68)

Union of Soviet Socialist Republics (USSR), and were requisitioned by the Resource Commission of Nationalist Government, finally becoming a very important part of state-owned enterprises in the People's Republic of China as a result of the 1949 revolution. The army of the USSR took over six of the nine furnaces in the Anshan Foundry and two of the four furnaces in the Benxihu Foundry. In spite of such big losses, 1,300,000 tons of iron was produced by the two foundries in 1953, which accounted for $60 \%$ of total Chinese iron production. The remaining Japanese engineers and newly dispatched Russian engineers cooperated with the Chinese to rebuild the foundries in Manchuria (Matsumoto 2000). In addition, Shijingshan Foundry and some other small foundries were developed in northern China by Japan during the Sino-Japanese War, and they too became part of the state-owned enterprises of the People's Republic of China.

\subsubsection{Development of the Small-Mill Cotton Industry as an Example of Labor-Intensive Industrialization in China}

One of the factors that supported the production of cotton yarn and products in the People's Republic of China was the development of many small cotton mills in the countryside. Despite the low-efficiency of their machinery, these small cotton mills used cheap labor in the countryside to realize cheap products that could compete in the market. In Jiangnan in the lower Yangzi Delta, small cotton mills moved from Japanese-controlled cities to the countryside during the Sino-Japanese War. 
In Wuxi, one area in which these small mills developed, there were seven big modern cotton mills with the total of 237,000 spindles. However, three mills burned down and the other four mills were damaged in October 1937 in the midst of the Sino-Japanese War. Only 45,000 spindles of the Qingfeng and Zhenxin Cotton Mills were in operation in the summer of 1939 (Koain 1940: 294). The first response to this situation was to move the cotton mills to the foreign settlement in Shanghai, where they could continue to operate safely, using imported raw cotton and selling their products in Shanghai's large market. The second response was to reopen the mills under Japanese control in occupied cities. However, both responses produced limited results as foreign trade became difficult after the start of the Asia-Pacific War at the end of 1941. As a third response, some of the Chinese cotton mills moved their equipment to the countryside, separating it among many small mills. According to statistics published by the Preparatory Association of the Shanghai Cotton Industry in 1947, in Jiangnan district alone there were 16 large cotton mills each equipped with an average of 31,031 average spindles and 57 small cotton mills equipped with an average of 2,979 spindles (Shanghai-shi Mianfangzhi Gongye Tongyegonghui Choubeihui 1950).

Among the semi-official books on local history one finds explanations such as the following:

Cotton mills in Shanghai, Wuxi, and Suzhou, one after another, removed a large proportion of their spinning machines and brought them to cotton-growing areas such as Changshu County to establish new small mills. Twenty small mills equipped with 41,092 spindles were established in Changshu County in Jiangsu Province. (Changshu shi Difangzhi Biansuan Weiyuanhui 1991: 337)

In 1944, Litai Cotton Mill in Taicang County in Jiangsu Province used their equipment and capital to establish more than 10 new mills in different places. These small mills were each equipped with about 2,000 spindles. (Changshu shi Difangzhi Biansuan Weiyuanhui 1991: 272)

Small mills built in cotton-growing areas could easily obtain cheap raw cotton and then supply cotton products during the wartime period, thereby securing large profits (Zhongguo Jindai Fangzhishi Bianweihui 1996-1997: II 34). With these small mills increasing their demand for cotton yarn, small dye houses and weaving mills also profited and were able to develop. These mills got good results because most of them were located in old, cheap buildings and used simple equipment such as charcoal engines (Zhongguo Jindai Fangzhishi Bianweihui 1996-1997: I 277-278). Most of them were equipped with cheap secondhand spinning machines, although some of them introduced a new simplified spinning machine called a Xinnong shi Fangjiji (Xinnong-type Spinning Machine) (Zhongguo Jindai Fangzhishi Bianweihui 1996-1997: I 43). It should be noted that appreciation for the significance of such small mills was spreading among Chinese engineers. For example, when Zhang Fangzuo, (1901-1980, graduate of Tokyo Technical High School), manager of Xinyu Cotton Mill in Shanghai, wrote a textbook to educate engineers, he recommended establishing a small mill equipped with 1,200 spindles. He pointed out that such small mills were suitable for meeting contemporary demand, were easy to start a new 
business, and were beneficial for the rural economy (Zhang 1945: 127-128). Thus, such viewpoints began to act as footlights for the arrival of the People's Republic of China.

However, small mills in the countryside lost their competitive edge after the end of the Sino-Japanese War, when the electricity supply was returned to the cities and cheap raw cotton could be imported from America. In addition, as the transportation system was disturbed as a result of the civil war, it became difficult to bring raw cotton from Jiangbei to the cotton market in Jiangnan. These conditions put pressure on cotton mills in Wuxi district to stop operation (Zhenhuai 1946) and it seemed that the era of small mills was over. Many small mills moved back to the cities from the countryside and were merged with big mills. For example, in Changshu, a famous mill district in the countryside, Jinfeng Mill moved to Hankou, Fusheng Mill moved to Weinan, Taishan Mill and Changan Industrial Company moved to Nanjing, Dakang Mill was merged with Anda Mill in Shanghai, and Yongfeng Mill and Home Industrial Company were merged with Qingfeng Mill in Wuxi (Changshu shi Difangzhi Biansuan Weiyuanhui 1991: 338). In Taicang, another famous mill district in the countryside, most of the small cotton mills were merged with big cotton mills in cities and only one cotton mill, Litai Cotton Mill, existed in 1956 (Taicang xian Xianzhi Biansuan Weiyuanhui 1991: 272).

Nevertheless, many small cotton mills in Jiangnan revived at the end of 1950s. Many small mills reopened when the Department of the Cotton Industry of the central government of the People's Republic of China transferred the right to establish mills to local governments on 7 March 1958, the eve of the Great Leap Forward (Guojia Jingji Maoyi Weuyuanhui 2000: 313-314). In the case of Jiangyin County, most small cotton mills managed by the Peoples Commune emerging from the end of the 1950 s to the 1960 s used old equipment and could make only coarse yarn (Jiangyin xian Xianzhi Biansuan Weiyuanhui 1992: 370). It is likely that the level of technology of such small mills was similar to those established during the Sino-Japanese War.

Small cotton mills began to revive in Jiangnan in the 1970s. Many small cotton mills came and went in accordance with demand and supply. Such factors certainly continued to support the production of cotton products in the People's Republic of China since 1950s. In the background, there was the experience during SinoJapanese War. Undoubtedly, some of the policy makers in the Department of the Cotton Industry and the other governmental organizations intentionally revived the industrialization process during the War. Thus Zhang Fangzuo, the engineer who stressed the importance of small cotton mills during the war, became a leading figure at the Institute of Spinning and Weaving Science in the People's Republic of China. 


\subsection{Wartime Controlled Economy Under the Nationalist Government: The Controlled and Planned Economy Before Mao's Era}

Economic policy played a very important role in China's economic development. With regard to a controlled economy, in particular, the attitudes of modern Chinese governments went through significant changes. Such changes could not be explained away by the difference between the Nationalist government and the Communist government, as under the Nationalist government, there was a period of controlled economy and a period of open economy. After the Communist government emerged, the range of changes in economic policy became much wider than the period of the Nationalist government. In a controlled economy the state puts most economic activities under its direct control. By contrast, in an open economy intervention in economic activities by the state is kept to a minimum and the open market plays an important role. Needless to say, there are various economic systems between these two extremes. Furthermore, in a planned economy the state decides various economic targets to ensure that the economy develops according to a predetermined plan. A planned economy is closely related to a controlled economy and this was a characteristic of the USSR type of socialism in the 20th century (Elleman 1979).

\subsubsection{Economic Construction by the Nationalist Government on the Eve of War}

As most western countries adopted controlled economy policies to defend against economic depression and the Union of Soviet Socialist Republics spread propaganda hailing the success of their planned economy, many countries began to consider the idea of a controlled and planned economy during 1930s. The idea of a controlled or planned economy also became active in China under the Nationalist regime. However, the economic policies of the Nationalist government originally proceeded along the lines of a protective tariff policy to promote domestic industries and currency reform to unite and stabilize the Chinese currency (Kubo 1999). No one was thinking of a controlled and planned economy, including the former leader of the Nationalist Party, Sun Yatsen, in his grand plan for economic construction written in 1910s. As a result, in spite of many calls for implementing a controlled and planned economy, the Nationalist government refused.

The National Economic Committee established under the National Government in 1931 was very active from 1933 to 1938, when it was absorbed into the Department of Economy. The committee comprised officials in the relevant government departments, famous entrepreneurs in private enterprises, and specialists and engineers from industry. The NEC succeeded in improving the quality of the raw cotton, cocoon, and tea, constructing national highways, expanding the irrigation system by using foreign aid, including American loans, and cooperating with the League 
of Nations (Kawai 1982). Thus, the NEC was instrumental in promoting economic development led by private enterprises in the light industry in the 1930s.

The vice-chairman of the NEC, Song Ziwen, in his address to the members of the committee, stressed that the state would help private enterprises. Although he specifically mentioned a controlled economy, his position was far from supporting a true controlled economy. At that time, one of the economists criticized the NEC, saying that it was not the organization to implement a controlled economy and that this interest in a controlled economy was only a passing fad. In reality, although a controlled economy was often mentioned, their real intentions were actually closer to an open economy (Kubo 1996).

In contrast, the Resource Commission, led by the many technocrats in the Nationalist government, clearly announced their intention to promote development under a controlled and planned economy from the latter half of the 1930s to the 1940s. At first, the Resource Commission was a secret commission, established as the Defense Planning Committee under the General Staff of the Nationalist Army in 1932; however, it was reorganized as the Resource Commission under the Military Committee of the Nationalist Government in 1935. In 1938, the Resource Commission was again reorganized and enlarged under the Department of the Economy. The Resource Commission promoted the establishment of a controlled and planned wartime economy, attaching importance to heavy and chemical industries, strengthening development of inner districts, and using barter trade comprising the export of strategic materials and import of machinery and equipment. This viewpoint helped the Resource Commission achieve its aim (Zheng et al. 1991; Ishikawa 1991).

Weng Wenhao, the Head of the Resource Commission, was a respected geologist in China, receiving his doctoral degree from Ruben Catholic University in Belgium. He was appointed Secretary of Executive-Yuan by the Nationalist government in 1935 and led Chinese economic policy during the very difficult period during and after the Sino-Japanese War. In 1933, before his appointment, Weng already knew about the five-year plan of the USSR and its economic system, and had criticized the economic policy of the Nationalist government saying that it did not have systematic planning (Kubo 1996).

The leading organization of the economic policy of the Nationalist government changed from the NEC to the Resource Commission in the 1930s, and the basic thought on economic development changed from an open economy to a controlled economy accordingly. The outbreak of the Sino-Japanese War accelerated this change. The Nationalist government had other organizations related to economic policy, including the Construction Committee, which mainly supervised power stations, and the Department of Industry, which promoted an export-orientated policy under Chen Gongbo until 1937, but the basic trend was not influenced by the activities of such organizations. 


\subsubsection{Wartime Economy Under the Nationalist Government}

The Nationalist government moved from Nanjing to Chongqing, the preliminary capital, to continue its resistance against Japan. The government promoted the establishment of new factories in inner districts such as Sichuan or Yunnan to strengthen Chinese economic power for the Resistance War, and some of the industrial factories in the coastal districts moved to inner districts. The Chongqing government invested state funds to establish modern iron foundries, machine factories, electronic factories, and chemical factories, which supported the state-owned munitions industry. The Resource Commission played a decisive role in these activities. According to statistical data, industrial production in Free China increased more than 50\% from 1938 to 1942. However, in spite of such growth, the ratio of Free China's industrial production of the total national industrial production reached only about $10 \%$ and the quality of industrial products was poor (Kubo 2004). Nevertheless, the historical perspective that China could resist invasion by developing a state-owned munitions industry in its inner districts seriously influenced the management of China's economy after the end of the Sino-Japanese War.

Policies for trade control were an important aspect of the controlled economy of the Nationalist government. First, the government tried to stop trading with Japaneseoccupied areas after the Sino-Japanese War started. At the same time, it established the Trade Adjustment Commission under the Military Committee in October 1937, conducting collective purchases and sales for exporting agricultural products and ores through their three state-owned trade companies. The Trade Adjustment Commission was reorganized to become the Trade Commission under the Department of Finance in February 1938. The Trade Commission aimed to maintain a trade balance to continue importing munitions and securing foreign loans. Although several problems occurred, such as corruption of officials, the controlled trade system allowed the government to use transportation efficiently and adjust trading price adequately (Zheng 2004).

However, the situation changed after the outbreak of the Asia-Pacific War. Because trade routes between Free China and the outside world were almost stopped, the lack of various materials became more serious in Free China. So the Chongqing government changed the aim of its trade policy to acquire materials, promulgating a new act on 11th May 1942. This loosened the control of trade to allow the imports of materials essential for the construction of defense base and the daily necessities of the population.

Another control policy concerned the control of price and production. As the amount of food and cotton goods in the market decreased, their price increased in Free China. The Chongqing government tried to limit the price of several foodstuffs and cotton goods in the largest cities. In addition, the government pursued collective purchase and sale of such materials; however, the results were limited. For example, in the case of raw cotton, as the supply decreased, the production of cotton yarn also decreased. Cotton farmers did not want to sell their raw cotton for the low price decided by the government, and so a considerable amount of raw cotton flowed 
out from Free China to Japanese-occupied areas. Furthermore, under the controlled economy, private cotton mills ceased operation (Feng 1948).

Thus, the policies of a controlled economy realized by the Chongqing government obtained limited results, because the government was not powerful enough to pursue the necessary policies and the wartime circumstances limited the supply of materials.

\subsubsection{Other Phases of the Wartime Economy}

It was not only in Free China that the number of state companies increased and a controlled economy developed. Powerful policies of a controlled economy were executed in Manchuria and north China by Japan while under the Japanese occupation. In Manchuria, the Japanese Kanto (Guandong) Army decided on a "Five-year industrial development plan" to establish a "Manshu koku (State of Manchuria)" in the lead up to the outbreak of the Sino-Japanese War. However, after the war started, the Japanese government demanded enlargement of the original plan to supply sufficient materials such as steel, coal, and magnesium for the production of munitions. Japan invested five billion yen and made intensive efforts for the exploitation of several resources (Yamamoto 2003). However, although the steel and coal industries developed, only a partially developed industrial structure was built, and left as a legacy after the war.

In central China, the state-owned development company Naka-Shina Shinko Kabushiki Kaisha, capitalized with 100 million yen, was established by Japan in August 1938. The Japanese government invested half of the capital and private Japanese companies invested the other half. Naka-Shina Shinko Kabushiki Kaisha wanted to develop and manage the transportation, communication, electricity, mining, and fishery industries in occupied areas of central China. Similarly, Kita-Shina Kaihatsu Kabushiki Kaisha, capitalized with 350 million yen, was also established in north China in November 1938. Subsequently, supported by both these state-owned companies, many Japanese private companies came to China to run their business. In north China, iron foundries reached a production capability of 756,000 tons per year and a large electricity transmission network was constructed (Ju and Zhang 1997). This electricity network played an important role in the controlled and planned economy of the People's Republic of China (Tajima 2008).

The trend to develop state companies and adopt a controlled economy increased in Free China, Manchuria, and Japanese-occupied areas of China. The content and range of control differed in these areas and they could not usually get good results, except for the Resource Commission's activities in Free China and the partial industrial development in Manchuria. Nevertheless, the experience of economic development by state companies and controlled economy during the war period influenced Chinese management of the post-war economy. 


\subsection{Concluding Remarks}

One of the historical roots of industrialization in China was certainly the investments and various economic policies made by the state, but the role of the state was limited in the 19th century. The influence of the global economy, including foreign trade and investment, strongly promoted Chinese industrialization in its early stage.

China's struggle toward becoming a modern nation state started at the end of the Qing dynasty and continued through the Republican period. Many private enterprises developed under the various protectionist policies pursued by the newly emerging nation state. In particular, the protective tariff and currency reform of the Nationalist government played a decisive role.

Two kinds of industrialization can be seen in modern China from the 19th to the 20th century-capital-intensive industrialization characterized by the development of the large cotton mills in Shanghai and the Japanese iron foundries in Manchuria, and labor-intensive industrialization characterized by the development of the small cotton mills in Jiangnan, and both types of industrialization proceeded simultaneously.

The sphere of the state's economic activities widened from the 1940s to the 1970s under a controlled and planned economy, as China adopted a wartime economy first against the Japanese invasion and then against the United States of America and the Union of Soviet Socialist Republics. The development of state companies and adoption of a controlled economy increased in Free China, Manchuria, and Japaneseoccupied areas during the Sino-Japanese War, and this trend was continued and strengthened during Mao Zedong's era. As a result, although heavy industries and munitions industry developed, the process of industrialization faced many problems. At the end of the 1970s, after China opened its door to the world again, industrialization in China began to proceed under an intimate relationship with the global economy. It also involved a much greater number of private enterprises, ranging from large enterprises in cities and smaller enterprises throughout the country to lots of small-scale industrial activities in the countryside.

\section{References}

Changshu shi Difangzhi Biansuan Weiyuanhui. (1991). Changshu-shi Zhi (History of Changshucity). Shanghai: Shanghai Renmin Chubanshe.

Chuan, H. (1972). Han-ye-ping Gongsi Shilue (A brief history the Han-ye-ping Iron and Coal Mining and Smelting Company 1890-1926). Hong Kong: The Chinese University of Hong Kong.

Elleman, M. (1979). Socialist Planning. Cambridge: Cambridge University Press.

Feng, S. (1948). Minyuanlai woguo zhi mianfangzhi gongye (Cotton industry in China from 1912). In S. Zhu (Ed.) Minguo Jingjishi (The economic history of Republican China). Shanghai: Yinhang Zhoubao She.

Guojia Jingji Maoyi Weuyuanhui (National Economic and Trade Committee). (2000). Zhongguo Gongye wushi nian (The fifty years of China's industry). Beijing: Jingji Chubanshe. 
Hagiwara, M. (2000). Chugoku no Keizaikensetsu to Nicchukankei: Tainichikosen heno Jokyoku 1927-1937nen (China's economic construction and Sino-Japanese relationship: a prelude for the resistance war against Japan, 1927-1937). Kyoto: Mineruva Shobo.

Hatano, Y. (1961). Chugoku Kindai Kogyoshi no Kenkyu (A study on the history of Chinese modern industry). Kyoto: Toyoshi Kenkyukai.

Ishikawa, Y. (1991). Nankinseifu-jiki no gijutsu-kanryo no keisei to hatten: Kindai-Chugoku gijutsusha no keifu (The formation and development of technocrats in the Nanjing Government Era). Shirin, 7(2).

Jiangyin shi Xianzhi Biansuan Weiyuanhui. (1992). Jiangyin-shi Zhi (History of Jiangyin-city). Shanghai: Shanghai Renmin Chubanshe.

Ju, Z., \& Zhang, L. (1997). Riben zai Huabei Jingji Tongzhi Luetuo-shi (The history of Japanese plunder and economic control in North China). Tianjin: Tianjin Guji Chubanshe.

Kawai, S. (1982). Zenkokukeizaiiiinkai no seiritsu to sono kaiso o meguru ici-kosatsu (A survey on the establishment and reorganization of the National Economic Committee). Toyoshi Kenkyu, 40(4).

Kawai, S. (1987). Sengochugoku boshokugyo no keisei to Kokuminseifu: Chugoku boshoku konsu no seiritsukatei (The formation of China's cotton industry and the National Government after the World War II: The process of the establishment of the Chinese cotton industry constructing Company). Kokusaikankeiron Kenkyu, 6.

Kiyokawa, Y. (1983). Chugoku senyi-kikai kogyo no hatten to zaikabo no igi (The development of China's fiber machine industry and the meaning of Japanese cotton mills in China). Keizaikenkyu, 34(1).

Koain. (1940). Mushaku Kogyo Jittaichosa Hokoku-sho (A survey report of Wuxi Industry). Tokyo: Koain Seimubu. Chosashiryo 18.

Kubo, T. (1996). Kin-gendai Chugoku ni okeru kokka to keizai: Chuka minkoku-ki keizai seisakushiron (State and economy of modern and contemporary China: Understanding the history of economic policy of the Republican period). In T. Yamada (Ed.) Rekishi no nakano Gendai Chugoku (Contemporary China in the History). Tokyo: Keiso Shobo.

Kubo, T. (1999). Senkanki Chugoku< Jiritsu eno Mosaku > : Kanzei Tsuka Seisaku to Keiza Hhatten (China's quest for sovereignty in the interwar period: Tariff policy and economic development). Tokyo: Tokyo Daigaku Shppankai.

Kubo, T. (2004). Senji no kogyo seisaku to kogyo hatten (Industrial policy and development during the war-time). In N. Ishijima \& T. Kubo (Eds.) Jukei Kokuminseifushi no Kenkyu (History of the Chongqing National Government). Tokyo: Tokyo Daigaku Shuppankai.

Kubo, T. (Ed.). (2012). Chugoku Keizaishi Nyumon (An introduction to China's economic history). Tokyo: Tokyo Daigaku Shuppankai.

Kubo, T. et al. (2016). Tokei de Miru Chugoku Kin-gendai Keizaishi (Economic history of modern China: An approach based on statistical data). Tokyo: Tokyo Daigaku Shuppankai.

Matsumoto, T. (2000). “Manshu-koku” kara Shin Chugoku e: Anzan Tekkogyo karamita Chugokutohoku no Saihenkatei, 1940-1954 (From "the state of Manchuria” to New China: Reorganizing process seen from the Anshan Steel Industry 1940-1954). Nagoya: Nagoya Daigaku Shuppankai.

Murakami, K. (1982). Okura Zaibatsu no Kenkyu: Okura to Tairiku (A study on Okura Financial Group: "Okura" and Mainland). Tokyo: Kondo Shuppansha.

Nakai, H. (1996). Choken to Chugoku Kindai Kigyo (Zhang Jian and Chinese Modern Enterprise). Hokkaido: Hokkaido Daigaku Tosho Kankokai.

Nakura, B. (1984). Nihon Tekkogyoshi no Kenkyu (A study on the history of Japanese Steel Industry). Tokyo: Kondo Shuppansha.

Onoe, E. (1971). Chugoku Sangyoricchi no Kenkyu (A study on regional distribution of China's Industry). Tokyo: Institute of Developing Economies.

Shanghai-shi Mianfangzhi Gongye Tongyegonghui Choubeihui (Preparatory Association of the Shanghai Cotton Industry). (1950). Zhongguo Mianfang Tongji Shiliao (Historical statistics of China's Cotton Industry). Shanghai. 
Suzuki, T. (1992). Yomu Undo no Kenkyu (A study of the westernization movement in China in the latter half of the nineteenth century). Tokyo: Kyuko Shoin.

Taicang xian Xianzhi Biansuan Weiyuanhui. (1991). Taicang-xian Zhi (History of Taicang County). Nanjing: Jiangsu Renmin Chubanshe.

Tajima, T. (2008). Gendai Chugoku no Denryoku Sangyo (Electric power industry of contemporary China). Kyoto: Showado.

Takamura, N. (1982). Kindai Nihon Mengyo to Chugoku (The modern Japanese cotton industry and China). Tokyo: Tokyo Daigaku Shuppankai.

Tanaka, M. (1973). Nisshin senso-go no Shanhai kindai "gaisho" boseki-gyo to Chugoku shijo (Shanghai foreign-owned modern cotton industry and Chinese market after Sino-Japanese War of 1894). In H. Yamada (Ed.), Shokuminchi Keizaishi no Shomondai (Several problems in the history of colonial economies). Tokyo: Institute of Developing Economies.

Wang, Z. (1990). Gudao-shiqi de minzu mianfang gongye (National cotton industry in the so-called solitary island era). In Zhongguo Jindai Jingjishi Yanjiu Ziliao (Materials of Chinese modern economic history) 10. Shanghai: Shanghai Shehui Kexueyuan Chubanshe.

Yamamoto, Y. (2003). "Manshu-koku” Keizai-shi Kenkyu (A study on economic history of "The State of Manchuria"). Nagoya: Nagoya Daigaku Shuppankai.

Zhang, F. (1945). Mianfangzhi Gongchang zhi Sheji yu Guanli (Plan and management of cotton mill). Shanghai: Kaiming Shudian.

Zhenhuai. (1946). Zuijin Wuxi fangzhiye de gaikuang (Recent outlook of cotton industry in Wuxi). Jingji Zhoubao, 2(2).

Zheng, H. (2004). Boeki tosei seisaku (The policy of controlled trade). In N. Ishijima \& T. Kubo (Eds.) Jukei Kokuminseifushi no Kenkyu (History of the Chongqing National Government). Tokyo: Tokyo Daigaku Shuppankai.

Zheng, Y., et al. (1991). Jiu-Zhongguo de Ziyuan Weiyuanhui (1932-1949): Shishi yu Pingjia (The Resource Commission in Old China, 1932-1949: Facts and estimation). Shanghai: Shanghai Shehuikexue Chubanshe.

Zhongguo Jindai Fangzhishi Bianweihui. (1996-1997). Zhongguo Jindai Fangzhishi (shang-ce, xia-ce) (History of Chinese modern fabric industry (1)-(2)). Beijing: Fangzhi Chubanshe.

Open Access This chapter is licensed under the terms of the Creative Commons AttributionNonCommercial-NoDerivatives 4.0 International License (http://creativecommons.org/licenses/bync-nd/4.0/), which permits any noncommercial use, sharing, distribution and reproduction in any medium or format, as long as you give appropriate credit to the original author(s) and the source, provide a link to the Creative Commons licence and indicate if you modified the licensed material. You do not have permission under this licence to share adapted material derived from this chapter or parts of it.

The images or other third party material in this chapter are included in the chapter's Creative Commons licence, unless indicated otherwise in a credit line to the material. If material is not included in the chapter's Creative Commons licence and your intended use is not permitted by statutory regulation or exceeds the permitted use, you will need to obtain permission directly from the copyright holder.

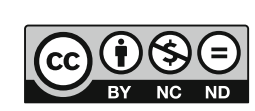

